\title{
KECERNAAN NDF DAN ADF PAKAN LENGKAP BERBASIS TEBON JAGUNG PADA SAPI FH
}

\author{
Cindy P. Ransa, R. A. V. Tuturoong*, A. F. Pendong, M. R. Waani
}

Fakultas Peternakan Universitas Sam Ratulangi Manado

\begin{abstract}
ABSTRAK
Tujuan dari penelitian ini untuk mengetahui konsumsi dan kecernaan NDF dan ADF pakan lengkap berbasis tebon jagung pada sapi FH. Materi percobaan yang digunakan adalah 14 ekor sapi perah $\mathrm{FH}$, berumur $7-8$ tahun dengan bobot antara 300 $-400 \mathrm{~kg}$, Pakan perlakuan, terdiri dari: $\mathrm{Ra}=$ $30 \%$ pakan konsentrat $+70 \%$ tebon jagung dan perlakuan $\mathrm{Rb}=30 \%$ konsentrat $+35 \%$ tebon jagung $+35 \%$ rumput raja. Metode penelitian adalah percobaan biologis, dengan analisis statistik uji $\mathrm{T}$ dua contoh dengan ragam tidak sama (t-test two sample assuming unequal varience). Variabel yang diamati yaitu konsumsi dan kecernaan NDF dan ADF. Hasil analisis uji T menunjukkan bahwa Konsumsi NDF perlakuan Rb berbeda tidak nyata $(\mathrm{P}>0,05)$ dibanding $\mathrm{Ra}$, sedangkan konsumsi ADF, serta kecernaan NDF dan ADF perlakuan $\mathrm{Rb}$ berbeda sangat nyata $(\mathrm{P}<0,01)$ dengan perlakuan $\mathrm{Ra}$. Dapat disimpulkan bahwa kecernaan NDF dan ADF pakan lengkap yang terdiri dari konsentrat, tebon jagung dan rumput raja lebih baik, dibandingkan pakan lengkap yang terdiri dari konsentrat dan tebon jagung.
\end{abstract}

Kata Kunci : konsumsi, kecernaan, NDF, ADF, pakan lengkap, sapi FH.

*Korespondensi (corresponding author): Email: ronny.tuturoong@yahoo.com

\section{ABSTRACT}

\section{NDF AND ADF DIGESTIBILITY} OF COMPLETE FEED OF CORN FORAGE IN FH CATTLE. The purpose of this study was to determine the consumption and digestibility of NDF and ADF based on corn forage based feed in $\mathrm{FH}$ cattle. The experimental material used was $14 \mathrm{FH}$ dairy cows, aged 7-8 years with weights between $300-400 \mathrm{~kg}$, treatment feed, consisting of: $\mathrm{Ra}=30 \%$ concentrate feed $+70 \%$ corn forage and treatment $\mathrm{Rb}=30 \%$ concentrate + $35 \%$ corn forage $+35 \%$ king grass. The research method was a biological experiment, with a statistical analysis of the two-sample $\mathrm{T}$ test with unequal variation ( $t$-test two sample assuming unequal varience). The results of the $\mathrm{T}$ test analysis showed that the NDF consumption of $\mathrm{Rb}$ treatment was not significantly different $(\mathrm{P}>0.05)$ compared to $\mathrm{Ra}$, whereas the consumption of ADF, as well as the digestibility of NDF and ADF treatment of $\mathrm{Rb}$ was significantly different $(\mathrm{P}$ $<0.01)$ with Ra treatment. It can be concluded that the digestibility of NDF and ADF complete feed consisting of concentrate, corn forage and king grass is better, compared to complete feed consisting of concentrate and corn forage.

Keywords: Consumption, digestibility, NDF, ADF, complete feed, FH cattle. 


\section{PENDAHULUAN}

Sapi FH berasal dari negara yang memiliki iklim subtropis, tetapi sapi ini memiliki daya adaptasi yang tinggi sehingga banyak dikembangkan di negara-negara beriklim tropis termasuk Indonesia. Sapi FH memiliki kemampuan memproduksi susu tinggi dengan kadar lemak lebih rendah dibandingkan dengan bangsa sapi perah lainya. Produksi susu sapi perah FH di negara asalnya mencapai $6000-8000$ $\mathrm{kg} / \mathrm{ekor} / \mathrm{laktasi}$, sedangkan di Inggris sekitar $35 \%$ dari total populasi sapi perah dapat memproduksi hingga 8069 kg/ekor/laktasi (Arbel et al., 2001).

Di Indonesia produktivitas sapi perah masih rendah dengan produksi susu 10 liter/ekor/hari atau kurang lebih 3.050 kg/laktasi (Sudono et al., 2003). Produksi air susu dipengaruhi oleh jenis ternak, tempat ternak dipelihara serta kualitas dan kuantitas pakan yang diberikan.

Hijauan merupakan pakan yang sangat diperlukan dalam meningkatkan produktivitas ternak ruminansia. Hijauan berkualitas tinggi menjadi sumber pakan utama sehingga upaya pemanfaatan sumber pakan dalam negeri menjadi sangat penting untuk meningkatkan efesiensi produksi, dimana ketersediaan hijauan pakan yang tidak memadai baik kualitas maupun kuantitas yang berkelanjutan menjadi salah satu kendala dalam pengembangan usaha peternakan (Lasamadi et al., 2013). Pakan ternak dapat dikelompokkan menjadi dua jenis yaitu hijauan dan konsentrat. Pemberian ransum berupa kombinasi kedua bahan itu akan memberikan peluang terpenuhinya zat zat gizi dan biaya relatif rendah. Namun pemberiaan pakan hijauan ternyata belum mencukupi kebutuhan nutrien dari ternak sapi sehingga perlunya pemberian konsentrat.

Hijauan yang sering diberikan sebagai pakan oleh petani di daerah Sulawesi Utara adalah rumput raja dan tebon jagung. Rumput raja (Pennisetum purpupoides) adalah jenis rumput hasil persilangan antara Pennisetum purpureum (rumput gajah) dengan Pennisetum tydoides. Rumput raja mempunyai kandungan SK 26,20\% (Handayanta, 2001), PK 11,68\%, Ca 0,37\%, P 0,39\%, SK 25,48\% (Rumiyati, 2008), NDF 76,22\% dan ADF 46,75\% (Siswanto et al., 2016). Batang dan daun rumput raja berukuran lebih besar dibandingkan dengan rumput lainnya. Rumput raja memiliki pertumbuhan yang sangat cepat mengalahkan, rumput gajah. Produksi rumput raja sangat tinggi dapat mencapai 
1.076 ton rumput segar/ha/tahun (Suyitman et al., 2003) disitasi oleh (Suyitman, 2014).

Tebon jagung adalah seluruh tanaman jagung berupa batang, daun dan buah jagung muda yang umumnya dipanen pada umur tanaman 45-65 hari (Soeharsono dan Sudaryanto, 2006). Tanaman jagung memiliki kandungan nutrisi yaitu SK 25,2\%, $\mathrm{K} \quad 0,28 \%$, dan fosfor $0,23 \%$ (Erna dan Sarjiman, 2007), PK 12,06\%, SK 25,2\% (Heryanto et al., 2016). Tanaman ini adalah jenis tanaman biji-bijian dari keluarga rumput-rumputan (graminacea) yang sudah lama dikenal di Indonesia yang mempunyai nilai ekonomis tinggi. Selain buahnya sebagai sumber karbohidrat dan hasil sampingan seperti daun, tongkol, kelobot dan dedak jagung dapat dimanfaatkan sebagai komponen pakan ternak, baik secara langsung maupun setelah melalui proses pengolahan. Selain kaya akan nutrisi tebon jagung juga baik untuk pencernaan ternak sapi FH.

Konsumsi pakan merupakan sejumlah pakan yang dapat dikonsumsi ternak pada periode waktu tertentu, dan merupakan faktor penting yang akan menentukan aras, fungsi, dan respon ternak serta penggunaan nutrien yang ada di dalam pakan (Van Soest, 1994). Tinggi rendahnya konsumsi pakan pada ternak ruminansia sangat dipengaruhi oleh faktor - faktor eksternal (lingkungan), faktor internal (kondisi ternak itu sendiri) dan pakan yang diberikan.

Besarnya kecernaan menentukan banyaknya nutrien yang dapat dimanfaatkan untuk memenuhi kebutuhan hidup pokok dan pertumbuhan (Widya et al., 2008). Kecernaan (digestibility) didasarkan pada suatu asumsi bahwa zat makanan yang tidak terdapat dalam feses merupakan zat yang tercerna dan terabsorbsi. Faktor yang mempengaruhi kecernaan pakan adalah komposisi pakan, komposisi ransum, penyiapan pakan, faktor hewan dan jumlah pakan (Tillman et al.,1998).

Kualitas pakan ruminansia ditentukan oleh kecernaan NDF (Neutral Detergent Fiber) dan ADF (Acid Detergent Fiber) sedangkan kecernaan NDF dan ADF ditentukan oleh populasi dan aktivitas mikroba rumen, khususnya mikroba yang mampu dan mempunyai aktivitas selulolitik. Kecernaan NDF dan ADF mempunyai kolerasi yang tinggi dengan jumlah konsumsi hijauan pakan. NDF terdiri dari hemiselulosa, selulosa,lignin dan protein yang terikat pada dinding sel yang mudah larut dalam detergent netral sedangkan ADF merupakan zat yang terdiri dari lignin, selulosa yang mudah larut dalam detergent asam (Van Soest, 1994). 
Penelitian ini bertujuan untuk mengetahui pengaruh pemberian pakan lengkap bebasis tebon jagung terhadap kecernaan NDF dan ADF pada ternak sapi FH.

\section{MATERI DAN METODE PENELITIAN}

Penelitian ini dilaksanakan di Balai Pembibitan Ternak Desa Tampusu Kecamatan Remboken Provinsi Sulawesi Utara. Penelitian ini menggunakan 14 ekor sapi $\mathrm{FH}$, berumur $7-8$ tahun dengan bobot antara 300 - 400 kg. Kandang yang digunakan adalah kandang individual sebanyak 14 kandang yang dilengkapi dengan tempat pakan dan tempat minum.

Pakan yang akan digunakan dalam penelitian terdiri dari pakan penguat (konsentrat) dan pakan hijauan. Pakan konsentrat disusun dari bahan - bahan pakan, yaitu : jagung, dedak halus, bungkil kedelai, bungkil kelapa, tepung ikan, premix (suplemen, vitamin, mineral) dan garam. Pakan hijauan yang digunakan adalah rumput raja (Pennisetum purpupoides) dan tebong jagung. Komposisi nutrien pakan percobaan serta formulasi komposisi nutrien setiap perlakuan dapat dilihat pada Tabel 1 dan 2 .

\section{Metode Penelitian}

Penelitian menggunakan metode eksperimen, terdiri dari 2 perlakuan dimana masing - masing perlakuan terdiri dari 7 ulangan. Perlakuan yang di terapkan adalah: $\mathrm{Ra}=30 \%$ konsentrat $+70 \%$ tebon jagung $\mathrm{Rb}=30 \%$ konsentrat $+35 \%$ rumput raja + $35 \%$ tebon jagung.

\section{Analisa Data}

Penelitian ini menggunakan analisis Uji T dua contoh dengan ragam tidak sama ( $t$ test two sample assuming unequal varience) (Snedecor and Cochran, 1989; Derrick et al., 2017).

\section{Tatalaksana Penelitian}

Pelaksanaan penelitian ini dibagi menjadi 3 tahap yaitu:

\section{Tahap pendahuluan}

Pada awal penelitian ternak diberikan kesempatan untuk beradaptasi dengan pakan percobaan. Adaptasi pakan percobaan dilakukan selama 7 hari. Adaptasi dilakukan dengan tujuan untuk membiasakan ternak mengkonsumsi pakan percobaan dan untuk mengetahui jumlah konsumsi dari pakan percobaan yang diberikan secara ad libitum serta air minum disediakan setiap saat. Sebelum diberikan ke ternak, tebon jagung dan rumput raja dicacah terlebih dahulu dengan ukuran $\pm 5 \mathrm{~cm}$. Konsumsi ternak 
Tabel 1. Komposisi Nutrien Pakan Percobaan.

\begin{tabular}{lccc}
\hline \multirow{2}{*}{ Nutrien } & Konsentrat & $\begin{array}{c}\text { Tebon Jagung } \\
(\mathrm{TJ}) *\end{array}$ & Rumput Raja (RR)** \\
\cline { 2 - 4 } & \multicolumn{2}{c}{$\%$} \\
\hline Bahan Kering & 87,93 & 19,73 & 20,30 \\
Protein & 16,65 & 10,90 & 9,52 \\
Lemak Kasar & 10,75 & 2,17 & 3,14 \\
Serat Kasar & 11,23 & 33,21 & 31,26 \\
NDF & 27,23 & 69,81 & 73,52 \\
ADF & 14,39 & 40,20 & 44,49 \\
Ca & 0,73 & 0,39 & 0,35 \\
P & 0,82 & 0,23 & 0,28 \\
Abu & 9,11 & 7,67 & 9,38 \\
BETN & 40,48 & 46,05 & 44,98 \\
Energi Bruto (Kkal) & 3708,89 & 3791,00 & 3375,00 \\
\hline Keterangant
\end{tabular}

Keterangan:

* Menurut Tulung et al. (2020)

**Lab. Minat Nutrisi dan Makanan Ternak Fak. Peternakan UB (2019).

Tabel 2. Formulasi Pakan Perlakuan dan Komposisi Nutrien Pakan.

\begin{tabular}{lcc}
\hline \multirow{2}{*}{ Bahan Pakan } & \multicolumn{2}{c}{ Perlakuan } \\
\cline { 2 - 3 } & $\mathrm{Ra}$ & $\mathrm{Rb}$ \\
\hline Konsentrat & 30 & 30 \\
Rumput Raja & 0 & 35 \\
Tebon Jagung & 70 & 35 \\
\hline Total & 100 & 100 \\
\hline & & \\
Komposisi Nutrien (\%) & & \\
Protein Kasar & 12,63 & 12.1 \\
Serat Kasar & 26,60 & 25,92 \\
NDF & 57,03 & 58,32 \\
ADF & 32,45 & 33,95 \\
Ca & 0,48 & 0,46 \\
P & 0.40 & 0,41 \\
BETN & 44,37 & 44 \\
\hline
\end{tabular}

Keterangan : Dihitung berdasarkan Tabel 1. 
Konsumsi ternak dihitung dari konsumsi bahan kering.

\section{Tahap Pra-Koleksi}

Tiga hari sebelum pengambilan data koleksi, dilakukan pembatasan pemberian pakan sebanyak $80 \%$ dari rataan konsumsi pakan pada tahap pendahuluan. Tujuan pembatasan pakan dilakukan agar pakan yang diberikan dapat dikonsumsi secara keseluruhan dan tidak tersisa.

\section{Tahap Koleksi}

Pengukuran kecernaan berdasarkan metode koleksi total.Pada tahap ini, pakan tetap diberikan sebanyak 80\%. Feses ditimbang setiap defikasi dan diambil sampel 5\% untuk analisis. Pengumpulan feses dilakukan selama 5 hari begitu juga dengan pengambilan sampel pakan. Pada periode ini diambil sampel pakan yang nantinya akan dianalisis bersama dengan feses yang sudah dikeringkan dengan matahari dan di bawah ke laboratorium untuk penetapan kadar NDF dan ADF dengan metode Van Soest (1994).

\section{Variabel yang Diamati}

\section{Konsumsi NDF}

Konsumsi NDF diperoleh dari selisih antara NDF dalam pakan yang diberikan dengan NDF dalam pakan sisa.

\section{Konsumsi ADF}

Konsumsi ADF diperoleh dari
Selisih antara ADF dalam pakan yang diberikan dengan ADF dalam pakan sisa.

\section{Kecernaan NDF}

Kecernaan NDF\%

$$
=\frac{\text { Konsumsi NDF }- \text { NDF feses }}{\text { Konsumsi NDF }} \times 100
$$

4. Kecernaan ADF

$$
\begin{aligned}
& \text { Kecernaan ADF\% } \\
& =\frac{\text { Konsumsi ADF }- \text { ADF feses }}{\text { Konsumsi ADF }} \times 100
\end{aligned}
$$

\section{HASIL DAN PEMBAHASAN}

$$
\text { Data hasil penelitian tentang }
$$
pemberian konsumsi pakan lengkap berbasis tebon jagung terhadap kecernaan NDF dan ADF pada sapi perah dapat dilihat pada Tabel 3.

\section{Konsumsi NDF}

Rerata konsumsi NDF pada Tabel 3 memperlihatkan bahwa konsumsi NDF pada perlakuan Ra sebesar 4413,92 g/ekor/hari dan konsumsi NDF pada perlakuan Rb sebesar 4720,03 g/ekor/hari. Hasil analisis Uji T menunjukkan bahwa perlakuan memberikan pengaruh berbeda tidak nyata $(\mathrm{P}>0,05)$ terhadap konsumsi NDF pada sapi FH. Situmorang et al. (2013), menyatakan bahwa faktor yang berpengaruh terhadap konsumsi pakan adalah palatabilitas yang dipengaruhi 
Tabel 3. Nilai Rerata Konsumsi dan Kecernaan NDF dan ADF Pakan Lengkap Berbasis Tebon Jagung Pada Sapi FH.

\begin{tabular}{lcc}
\hline \multirow{2}{*}{ Parameter } & \multicolumn{2}{c}{ Perlakuan } \\
\cline { 2 - 3 } & $\mathrm{Ra}$ & $\mathrm{Rb}$ \\
\hline Konsumsi NDF (g/ekor/hari) & 4413,92 & 4720,03 \\
Konsumsi ADF (g/ekor/hari) & $2516,34^{\mathrm{a}}$ & $2756,34^{\mathrm{b}}$ \\
Kecernaan NDF (\%) & $70,63^{\mathrm{a}}$ & $79,69^{\mathrm{b}}$ \\
Kecernaan ADF (\%) & $65,58^{\mathrm{a}}$ & $74,17^{\mathrm{b}}$ \\
\hline
\end{tabular}

Keterangan : Superskrip yang berbeda pada baris yang sama menunjukkan perbedaan yang berbeda sangat nyata $(\mathrm{P}<0,01)$.

oleh beberapa faktor diantaranya bau, rasa, tekstur dan warna pakan.

\section{Konsumsi ADF}

Pada Tabel 3 memperlihatkan bahwa konsumsi ADF pada perlakuan Ra sebesar 2516,34 g/ekor/hari dan konsumsi ADF pada perlakuan $\mathrm{Rb}$ sebesar 2756,34 g/ekor/hari. Hasil analisis Uji T menunjukkan bahwa perlakuan memberikan pengaruh yang berbeda sangat nyata $(\mathrm{P}<0,01)$ terhadap konsumsi ADF.

Konsumsi $\mathrm{ADF} \mathrm{Rb}$ lebih tinggi dibanding Ra disebabkan kecernaan ADF Rb lebih tinggi dibanding $\mathrm{Ra}$ (dapat dilihat pada Tabel 3). Kecernaan dari bahan pakan yang tinggi dan laju aliran pakan keluar dari dalam rumen lebih cepat, membuat rumen lebih cepat kosong sehingga konsumsi meningkat. Menurut Nurfaini (2015) kecernaan yang cepat pada selulosa dan lignin, dapat meningkatkan konsumsi pada pakan, sehingga konsumsi NDF dan ADF juga meningkat. ADF merupakan bagian dari serat kasar yang terdiri dari selulosa, lignin, dan silika.

\section{Kecernaan NDF}

Rerata kecernaan NDF pada Tabel 3 memperlihatkan bahwa kecernaan NDF pada perlakuan Ra sebesar 70,63\% dan kecernaan NDF pada perlakuan Rb sebesar 79,69\%. Hasil analisis uji $\mathrm{T}$ menunjukkan bahwa kecernaan NDF perlakuan Rb berbeda sangat nyata $(\mathrm{P}<0,01)$ dengan perlakuan $\mathrm{Ra}$. Menurut Widyobroto et al. (2007), bahwa kecepatan degradasi karbohidrat yang sesuai dengan kecepatan degradasi protein akan meningkatkan efesiensi protein mikroba. Menurut Tillman et al (1998), bahwa kecepatan dari suatu bahan yang tercerna keluar dari saluran pencernaan menyebabkan lebih banyak ruang yang tersedia untuk penambahan pakan. Di dalam rumen protein akan dihidrolisis oleh mikroba menjadi asam -asam amino. Asam - asam 
amino akan dirombak menjadi ammonia. Kurang lebih $82 \%$ mikroba rumen menggunakan ammonia untuk perkembanganya (Siswanto et al., 2016). Menurut Hall dan Huntington (2008), dalam aspek sinkronisasi, nutrien sering mengacu pada penyediaan protein dan energi ke dalam rumen, sehingga nutrien tersedia secara bersamaan sesuai proporsi yang dibutuhkan oleh mikroba rumen. Hasil penelitian ini disebabkan karena adanya efek asosiatif antara nutrien dari pakan perlakuan yang menyebabkan kecernaan NDF pada perlakuan $\mathrm{Rb}$ lebih tinggi dibanding pada perlakuan Ra. Daya cerna suatu bahan pakan juga tergantung pada keserasian zat - zat makanan yang terkandung di dalamnya yang disebut juga dengan efek asosiasi (Tillman $e t$ al., 1998). Tuturoong et al. (2014) menyatakan bahwa kecernaan bahan pakan dipengaruhi oleh beberapa faktor antara lain komposisi kimia, frekuensi bahan pakan, bentuk fisik pakan, jenis pakan, umur tanaman, temperatur lingkungan, spesies ternak, umur ternak, keragaman antar individu ternak dan aktivitas mikroba.

\section{Kecernaan ADF}

Rerata kecernaan ADF pada Tabel 3 memperlihatkan bahwa kecernaan ADF pada perlakuan Ra sebesar 65,58\% dan kecernaan
ADF perlakuan $\mathrm{Rb} 74,17 \%$. Hasil analisis uji $\mathrm{T}$ menunjukkan bahwa perlakuan memberikan pengaruh yang berbeda sangat nyata $(\mathrm{P}<0,01)$ terhadap kecernaan $\mathrm{ADF}$. Kecernaan ADF pada perlakuan Rb lebih tinggi dibanding Ra. Hasil penelitian Anggraeny et al. (2015), menunjukkan bahwa Kualitas bahan pakan sumber serat asal limbah tanaman dapat dikoreksi dengan meningkatkan pertumbuhan mikroba rumen melalui sinkronisasi suplai protein dan energi ke dalam rumen karena peningkatan pertumbuhan mikroba rumen dapat meningkatkan kecernaan pakan dan sebagai sumber protein bagi induk semang. Hasil penelitian ini disebabkan karena adanya efek asosiatif.

Menurut Lardy et al. (2004) bahwa sinkronisasi melalui fermentansi bahan pakan sumber energi dan protein dapat menghasilkan pengaruh positif pada sintesis protein mikroba. Ginting (2005) menyatakkan bahwa proses perubahan nutrien pakan menjadi protein mikroba di dalam rumen membutuhkan lingkungan dan kondisi rumen yang optimal, diantaranya adalah penyediaan nutrien dalam jumlah banyak, komposisi yang tepat dan pada waktu yang tepat selain nitrogen $(\mathrm{N})$ dan energi, sintesis mikroba rumen membutuhkan nutrien berupa vitamin, 
mineral dan kofaktor seperti zink, belerang cobalt dan metionin.

\section{KESIMPULAN}

Dari hasil penelitian ini dapat disimpulkan bahwa kecernaan NDF dan ADF pakan lengkap yang terdiri dari konsentrat, tebon jagung dan rumput raja lebih baik dibandingkan pakan lengkap yang terdiri dari konsentrat dan tebon jagung.

\section{DAFTAR PUSTAKA}

Anggraeny, H. Soetanto, Kusmartono dan Hartutik. 2015. Sinkronisasi suplai protein dan energi dalam rumen untuk meningkatkan efesiensi pakan berkualitas rendah. Wartazoa 25(3): $107-116$

Arbel, G., D. Chalid, dan M. E. Ensminger. 2001. Karakteritik Sapi Perah Fries Holland. Institut Pertanian Bogor Press. Bogor.

Derrick, B., B. Russ, D. Toher, dan P. White. 2017. Test statistics for the comparison of means for two sample that include both paired and independent observations. Journal of Modern App. Stat. Methods 16(1): 137-157.

Erna, W. dan Sarjiman, 2007. Budidaya hijauan pakan bersama tanaman pangan sebagai upaya penyediaan hijauan pakan di lahan sempit. Jurnal Peternakan dan Lingkungan 7: 134 141.
Ginting, S.P. 2005. Sinkronisasi Degradasi protein dan energi dalam rumen untuk memaksimalkan produksi protein mikroba. Wartazoa Vol. 15(1): 1-10

Hall, M.B. dan G.B. Huntington. 2008. Nutrient Synchrony : Sound in Theory, Elusive in Practice. J Anim Sci. 86 : E287-E292.

Handayanta, E. 2001. Pengaruh substitusi rumput raja dengan pucuk tebu dalam ransum terhadap performan sapi jantan Friesan Holstein. Sains Peternakan. Vol I (2): 49-56.

Heryanto, K. Maaruf, S.S. Malalantang, M. R. Waani. 2016. Pengaruh pemberian rumput raja (Pennisetum purpupoides) dan tebon jagung terhadap performans sapi peranakan onggole (PO) betina. Jurnal Zootek 36(1): 123-130.

Lardy, G.P., D.N. Ulmer, V.L. Anderson, J.S. Caton. 2004. Effect of increasing level of supplemental barley on forage intake, digestibility and ruminal fermentation in steers fed medium quality grass hay. J Anim Sci. 82: 3662 3668.

Lasamadi, D. R., S.S. Malalantang, Rustandi, S.D. Anis. 2013. Pertumbuhan dan perkembangan rumput gajah Dwarf (Pennisetum purpureum cv. Mott) yang diberi pupuk organik hasil fermentasi EM4. Jurnal Zootek 32(5): 158-171.

Nurfaini, A. 2015. Konsumsi NDF dan ADF Pellet Pakan Komplit Berbasis Tongkol Jagung Dengan Sumber Protein Berbeda Pada Kambing Kacang Jantan. Skripsi. Fakultas Peternakan. Universitas Hasanuddin. Makasar. 
Rumiyati, 2008. Pengaruh imbangan jerami kacang tanah dan rumput raja dalam ransum terhadap performan sapi pfh. jantan. Jurnal Penelitian Ilmu Peternakan Fakultas Pertanian Universitas Sebelas Maret. Vol 9: 62 68

Siswanto, D. B. Tulung, K. Maaruf, M., R. Waani, M., M. Tindangen. 2016. Pengaruh pemberian rumput raja (Pennisetum purpupoides) dan tebon jagung terhadap kecernaan NDF dan ADF pada sapi PO pedet jantan. Jurnal Zootek 36(2): 379 - 386.

Situmorang, NA., L.D. Mahfudz dan U. Atmomarsono. 2013. Pengaruh pemberian tepung rumput laut (Gracilaria verrucosa) dalam ransum terhadap efesiensi penggunaan protein ayam broiler. Animal Agricultural 2(2): 49-56.

Snedecor, G. W. and W. G. Cochran.1989. Statistical Methods, Eighth Edition, Iowa State University Press.

Soeharsono dan B. Sudaryanto. 2006. Tebon Jagung Sebagai Sumber Hijauan Pakan Ternak Strategis di Lahan Kering Kabupaten Gunung Kidul. Prosiding. Lokakarya Nasional Jejaring Pengembangan Sistem Integrasi Jagung Sapi. Puslitbang Peternakan, Bogor. hlm. $136-141$.

Sudono, A., F. Rosdiana, dan B. S. Setiawan. 2003. Beternak Sapi Perah Secara Intensif. Agromedia Pustaka. Jakarta .

Suyitman, 2014. Produktivitas rumput raja (Pennisetum purpupiodes) pada pemotongan pertama menggunakan beberapa sistem pertanian. Jurnal Peternakan Indonesia 16(2): 119-127
Tillman, A.D., H. Hartadi, S. Reksohadiprodjo, S. Prawirokusumo, dan S Lebdosoekojo. 1998. Ilmu Makanan Ternak Dasar. Gadjah Mada University Pres, Yogyakarta.

Tulung, Y.L.R., A.F. Pendong, B. Tulung. 2020. Evaluasi nilai biologis pakan lengkap berbasis tebon jagung dan rumput campuran terhadap kinerja produksi sapi Peranakan Ongole (PO). Zootec 40(1): 363 - 379

Tuturoong, R. A. V., Hartutik, Soebarinoto, Ch. Kaunang. 2014. Evaluasi Nilai Nutrisi Rumput Benggala Teramoniasi dan Ampas Sagu Terfermentasi Dalam Pakan Komplit Terhadap Penampilan Kambing Kacang. Disertasi. Fakultas Peternakan Universitas Brawijaya. Malang.

Van Soest, P. J. 1994. Nutritional Ecology of the Ruminant. Second Edition. Comstock Publishing Associates Cornell University Press. A Division of Ithaca and London.

Widya, P.L., W.E. Susanto, A.B. Yulianto. 2008. konsumsi dan kecernaan bahan kering dan bahan organik dalam haylase pakan lengkap ternak sapi Peranakan Ongole. Jurnal Media Kedokteran Hewan 24(1): 59 - 62.

Widyobroto, B.P., S.P.S. Budi, A. Agus. 2007. Pengaruh aras undegraded protein dan energi terhadap kinetik fermentasi rumen dan sintesis protein mikroba pada sapi. J Indonesia Trop Anim Agric. 32(3):194 -200. 